\title{
The Effect of E-Filling and E-Billing Systems Implementation on Taxpayer Compliance with Understanding of the Internet as a Moderating Variable
}

\author{
Alfiyatul Umniyah ${ }^{1}$, Firdha Rahmiyanti ${ }^{2}$, Khoirul Anwar ${ }^{3}$, Fajar Adhitya ${ }^{4}$, Warno ${ }^{5}$, \\ Naili Saadah $^{6}$, Faris Shalahuddin Zakiy ${ }^{7}$, Herwening Sindu Lestari ${ }^{8}$, \\ Irma Istiariani ${ }^{9}$, Tri Widyastuti Ningsih ${ }^{10}$ \\ Universitas Islam Negeri Walisongo Semarang
}

\{alfiyatulumniyah1999@gmail.com¹ ${ }^{1}$, firdharyanti@walisongo.ac.id ${ }^{2}$, khoirul_anwar@walisongo.ac.id ${ }^{3}$ \}

\begin{abstract}
This study aims to determine the effect of of e-filling and e-billing systems implementation on taxpayer compliance with understanding of the internet as a moderating variable (empirical study on KPP Pratama Demak). This research uses quantitative methods. The type of data used in this study is primary data, where data sources can be obtained by distributing questionnaires. The population used in this study is that all taxpayers registered with the KPP Pratama Demak are 99,327 taxpayers. The sample used in this study amounted to 105 taxpayers, to calculate the number of samples in this study using the Slovin formula. The data analysis technique was assisted by the SPSS version 16.0 program. The results of this study indicate that the implementation of the efilling system (PSF) and the implementation of the e-billing system (PSB) has a positive and significant effect on taxpayer compliance (KWP). Understanding the internet cannot moderate the effect of applying the e-filling system to taxpayer compliance with a significant result of $0,305>0,05$. Internet understanding cannot moderate the effect of e-billing system implementation on tax compliance, with a significance value of $0,207>0,05$.
\end{abstract}

Keywords: Taxpayer Complianc; Implementation of E-Filling System; Implementation of E-Billing System; Internet Understanding

\section{Introduction}

Based on Law Number 16 of 2009, Taxes are contributions issued by taxpayers to the state which are coercive according to applicable laws. The tax law always changes, but these changes it does not change the characteristics of the tax collection system in the country of Indonesia, namely self-assessment, which means a system where taxpayers can calculate their dependent taxes, calculate the amount of tax owed and report to the tax office. By applicable regulations [1].

Taxes are used by the government to regulate and implement policies in the economic sector, but in reality, tax collection is still quite difficult to do, this is due to the low level of 
taxpayer compliance. Taxpayer compliance can be seen through the attitude of taxpayers to register, calculate taxes, report Tax Returns (SPT), comply with tax calculations and payments, and comply with arrears. The level of taxpayer compliance at KPP Pratama Demak cannot be done to the maximum. This can be seen from the taxpayer compliance statistics in table 1. Based on statistical data on taxpayer compliance at the Demak tax service office (KPP), it can be seen from all taxpayers who realized SPT reporting, both corporate taxpayers, employee OPs, and non-employee OPs in 2016, 2018, and 2019 have not been able to reach the number of taxpayers who should report SPT.

Table 1. Taxpayer Compliance Statistics Data

\begin{tabular}{|c|c|c|c|c|}
\hline & 2016 & 2017 & 2018 & 2019 \\
\hline 1. The amount of Taxpayer listed & 57.485 & 39.949 & 43.590 & 47.704 \\
\hline \multicolumn{5}{|l|}{ Required to SPT } \\
\hline a. Institution & 3.642 & 3.711 & 4.186 & 4.077 \\
\hline b. Private person Non Employees & 5.734 & 6.654 & 9.687 & 11.967 \\
\hline \multirow[t]{2}{*}{ c. Private person Employees } & 48.109 & 29.584 & 29.717 & 31.660 \\
\hline & 2016 & 2017 & 2018 & 2019 \\
\hline 2. The amount of SPT Realisation & 37.560 & 41.547 & 40.921 & 42.740 \\
\hline a. Institution & 2.182 & 2.341 & 2.520 & 2.698 \\
\hline b. Private person Non Employees & 1.827 & 4.014 & 6.609 & 9.391 \\
\hline c. Private person Employees & 33.551 & 35.192 & 31.792 & 30.651 \\
\hline
\end{tabular}

Source: KPP Pratama Demak

Table 2. Users of the Demak KPP Pratama KPP E-filling System

\begin{tabular}{lcccc}
\hline \multicolumn{1}{c}{ Description } & $\mathbf{2 0 1 6}$ & $\mathbf{2 0 1 7}$ & $\mathbf{2 0 1 8}$ & $\mathbf{2 0 1 9}$ \\
\hline The amount of realitation Taxpayer`s SPT & 37.560 & 41.547 & 40.921 & 42.740 \\
Taxpayer that uses $e$-filling & 12.768 & 26.682 & 31.936 & 38.276 \\
\hline
\end{tabular}

Source: KPP Pratama Demak

The Directorate General of Taxes (DGT) always strives to improve taxpayer compliance by improving and optimizing services, which are expected to increase the awareness and desire of taxpayers so that they can be orderly and trustworthy in fulfilling the taxes they bear. Besides, the Directorate General of Taxes (DGT) has also carried out tax administration reforms by making improvements in business processes that utilize information and communication technology through the application of an online SPT reporting system or efilling and online tax payments through e-billing. However, in reality, there are still quite a several taxpayers who have not used the e-filling facility. Table 2 describes the users of the efilling system at the Demak Tax Office (KPP).

Based on table 2 it can be explained that users of the e-filling system at KPP Pratama Demak from 2016 to 2019 have not been able to be implemented as much as possible, although each year has increased, it can be seen in 2019, the number of taxpayers who report SPT is 42,740 only 38,276 taxpayers who reported their SPT through e-filling.

To use e-filling and e-billing, taxpayers must utilize the internet network. Besides, taxpayers are also required to be able to operate the internet. Based on the results of a polling study in Indonesia in collaboration with the Indonesian Internet Service Providers Association (APJII), the number of internet users in Indonesia grew by $10.12 \%$. Henri said, out of a total of 264 million Indonesians, 171.17 million or around $64.8 \%$ of Indonesia's population already use the internet, this figure has increased from 2017 when internet presentation in Indonesia was $54.86 \%$ [2]. With a presentation of $64.8 \%$ of the Indonesian population who are already able to use the internet, of course, we can know that the growth and development of internet 
usage are quite high, so it is hoped that it can have a positive impact on the implementation of an even better e-filling and e-billing system.

Research related to taxpayer compliance, implementation of e-filling, and e-billing include research [3] [4] which shows that the implementation of e-filling and e-billing systems has a positive effect on taxpayer compliance. However, this statement is not in line with the research conducted by Arifin et al. [5] that the implementation of e-filling cannot have a significant effect on taxpayer compliance, while partially the impelementation of e-billing has no significant effect on taxpayer compliance.

From the description above, there is a discrepancy in the research results. Therefore, the researcher intends to review by adding one variable, namely understanding the internet as a moderating variable. Therefore, the authors conducted a study entitled The Effect of E-filling and E-billing System Implementation on Taxpayer Compliance with Understanding of the Internet as a Moderating Variable at KPP Pratama Demak.

\section{Literature Review}

\subsection{Attribution Theory}

Attribution theory is a theory that can explain the process by which we know the causes and motives that arise from a person's behavior [6]. Attribution theory is very appropriate to explain the factors that affect the level of taxpayer compliance that will be used in this study. Taxpayer compliance can be related to the attitude arising from the taxpayer to provide an assessment of the tax itself. Internal and external factors will influence a person in assessing other people and certain events [7]. In this study, researchers used attribution theory because researchers wanted to find out what factors could affect the level of taxpayer compliance.

\subsection{Technology Acceptance Model (TAM)}

According to [8] TAM is a theory that uses a behavioral theory approach which is widely used to study the process of information technology adoption. TAM theory is more devoted to explaining the behavior of people using computers (computer usage behavior). There are 5 constructs in the Technology Acceptance Model (TAM) according to [9], namely: perceived ease of use, perceived usefulness, attitude toward using, behavioral intention to use, and actual technology usage. Of the 5 constructs mentioned above, this study will use 2 perceptions, namely perceived ease of use and perceived usefulness which is one of the determinants of whether or not a system is acceptable [10].

\subsection{Taxpayer Compliance}

Taxpayer compliance can be interpreted as a situation where taxpayers can be responsible for fulfilling their obligations and rights in carrying out their taxation [11]. The issue of compliance is very important because concurrent non-compliance can lead to tax evasion, resulting in reduced tax funds depositing into the state treasury. From this explanation, it can be concluded that the higher the level of truth in calculating the amount of tax, the accuracy in terms of depositing and filling and submitting notification letters, it is hoped that this can make taxpayers more obedient in fulfilling their tax obligations [11]. 


\subsection{Implementation of the E-Filling System}

E-filling is a system used to submit SPT or for notification of annual SPT extensions that can be done online and in real-time, the reporting can be done through the online DGT tax efilling website provided by tax application service providers (ASP) [12].

\subsection{Implementation of the E-Billing System}

The e-billing system has been implemented since July 1, 2016, e-billing is an online tax payment system were to make these payments the taxpayer must create a billing code consisting of 15 digit numbers issued through the tax billing system. To create the billing code, taxpayers can do it through bank tellers, SMS ID billing, billing services at KPP, and $\mathrm{KP} 2 \mathrm{KP}$, as well as application service providers (ASP). Meanwhile, the payment process can be done through ATMs, internet banking, tellers at the bank (post office), or through mini ATMs at the local tax office or KP2KP [13].

\subsection{Understanding of the Internet}

Understanding the internet can provide many benefits in the form of information that users need, for example, it can make it easier to find information related to modern tax administration systems including those related to SPT reporting systems and online tax payments (e-filling and e-billing). Besides that, it is easy to find information related to laws and regulations on taxation, from this information, which will provide benefits especially for taxpayers [14].

By understanding the Internet, users can easily access various information, knowledge, and other important matters quickly, one example of which is that the internet will provide convenience and speed for taxpayers to access e-filling and e-billing systems [15].

\subsection{Hypotheses Formulation}

\section{a) The Effect of E-filling System Implementation on Taxpayer Compliance}

The TAM (Technology Acceptance Model) theory states that the use of technology systems is very influential in explaining individual behavior in assessing the convenience provided by advances in technology, e-filling is one of the systems created due to advances in technology.

The implementation of the E-filing system can improve taxpayer compliance in submitting annual tax returns. This is supported by research [16] explaining that the implementation of the e-filling system has a positive effect on taxpayer compliance, while the results of research conducted by [17]. Therefore, based on previous research and the arguments that have been elaborated, the following hypothesis can be proposed:

$H^{l}$ : The implementation of the e-filling system has a positive and significant impact on taxpayer compliance who is registered at KPP Pratama Demak. 


\section{b) The Effect of E-billing System Implementation on Taxpayer Compliance}

In addition to e-filling, in tax administration reform, the Directorate General of Taxes has also created a tax payment system that can be done online or known as e-billing, with ebilling, taxpayers do not need to queue at the queue when making tax payments which become dependents, with the convenience and satisfaction given to taxpayers, is expected to increase taxpayer compliance. This is supported by research [13] proving that the implementattion of the e-billing system has a positive effect on taxpayer compliance, while the research conducted by [5] proves that the implementation of e-billing has no significant effect on individual taxpayer compliance at KPP Pratama Medan Polonia. Therefore, based on previous research and the arguments that have been elaborated, the following hypothesis can be proposed:

$H^{2}$ : The implementation of the e-billing system has a positive and significant effect on taxpayer compliance registered at KPP Pratama Demak.

c) The Effect of E-filling System Implementation on Taxpayer Compliance with Internet Understanding as a Moderating Variable

Understanding the internet is an important thing that cannot be separated from the existence of a modern tax administration system, one of which is the online e-filling, filling, and reporting system of Tax Returns (SPT) through e-filling, making taxpayers required to understand how to operate the internet, if it is obligatory. Taxes do not understand this, so the ease of the e-filling system cannot be felt directly by taxpayers. Therefore the hypothesis proposed in this study are:

$H^{3}$ : Understanding the Internet can moderate the effect of the implementation of the E-filling system on the compliance of taxpayers who are registered in KPP Pratama Demak.

\section{d) The Effect of E-billing System Implementation on Taxpayer Compliance with Internet Understanding as a Moderating Variable}

Similar to e-filling, in using online e-billing, taxpayers are also required to understand or understand the internet. With the existence of an e-billing system in making tax payments online, it is hoped that taxpayers can increase the compliance of the taxpayers they depend on. This is in line with research [10] which shows that understanding the internet can moderate the implementation of e-billing to taxpayer compliance, based on the description above, the hypothesis to be formulated is:

$H^{4}$ : Understanding the Internet can moderate the effect of the implementation of the e-billing system on the compliance of taxpayers who are registered at KPP Pratama Demak.

\section{Methods}

The research used in this study uses quantitative methods with the form of survey research. This study uses 3 types of variables including dependent, independent, and moderating variable. The dependent variable in this study is taxpayer compliance, while the independent 
or independent variables are e-filling and e-billing systems, while the moderating variable is internet understanding. The data sources that will be used are primary data through questionnaires and secondary data obtained through books, journals, and the internet.

The data collection method in this study was carried out by distributing questionnaires. The questionnaire that will be distributed is related to the problem which is the object of the research. This questionnaire is given to Taxpayers registered at KPP Pratama Demak who have already used e-filling and e-billing.

\section{Result and Discussion}

\subsection{The Effect of E-filling System Implementation on Taxpayer Compliance}

Based on the results of data processing, the results of the study can be seen in Figure 1. The results of this study indicate that the e-filling system implementation variable has a positive and significant effect on the taxpayer compliance variable at KPP Pratama Demak. This research is proven by the results of the $t$ value of $7.942>t$ table value of 1.98397 with a significance value of $0.000<0.05$ so that this study succeeded in proving the first hypothesis, namely the application of the e-filling system has a positive and significant effect on taxpayer compliance variables in KPP Pratama Demak or H1 is acceptable.

\subsection{The Effect of E-billing System Implementation on Taxpayer Compliance}

The results obtained from this study prove that the variable of the implementation of the ebilling system has a positive and significant effect on taxpayer compliance at KPP Pratama Demak. These results can be proven by the value of $t$ count $>t$ table $(4.462>1.98397)$ with a significance of $0.000<0.05$, from these results it can be concluded that the implementation of the e-billing system can have a positive and significant effect on taxpayer compliance so that $\mathrm{H} 2$ is accepted.

\subsection{The Effect of E-filling System Implementation on Taxpayer Compliance with Internet Understanding as a Moderating Variable}

This study rejects H3 in the third hypothesis, this can be proven by the value of the t-test, where the moderate regression coefficient gives a value of -0.024 with a significance of $0.305>0.05$, this value means that the internet understanding variable cannot moderate the effect of system implementation. E-filling on the level of taxpayer compliance at KPP Pratama Demak.

\subsection{The Effect of E-billing System Implementation on Taxpayer Compliance with Internet Understanding as a Moderating Variable}

This study rejects $\mathrm{H} 4$ in the fourth hypothesis. This can be proven by the moderate value of the regression coefficient which is -0.045 with a significance of $0.207>0.05$, which means that the internet understanding variable does not moderate the effect of the implementation of the e-billing system on taxpayer compliance at KPP Pratama Demak. 


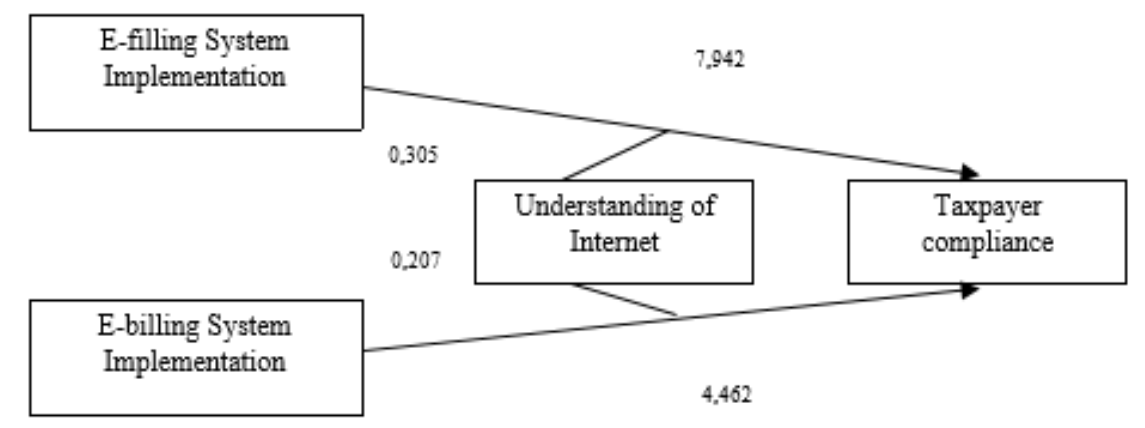

Fig. 1. Reseacrh Result

The implementation of the e-filling system can have a positive and significant effect but cannot dominate the level of taxpayer compliance, this is because e-filling is one of the systems created due to reforms in the field of tax administration established by DGT to make it easier for mandatory taxpayers. Taxes in reporting their SPT online, so that with the efilling, taxpayer compliance levels can increase. The results obtained from this study can support the results of previous studies conducted by [15]. The results showed that e-filling has a positive and significant effect on the compliance of individual taxpayers as civil servants.

The implementation of e-billing at the Pratama Demak tax service office has not been maximally implemented, this is because the e-billing system can only be accessed via the internet network so that accessing e-billing is still quite difficult, besides that, in accessing the usual system. Done together at the time of paying the annual SPT causing the system to become error (the system cannot be accessed). This study supports the previous research conducted by [18]. One of the results of his research shows that the implementation of the ebilling system can have a positive and also significant effect on the compliance of MSME taxpayers who are registered at KPP Pratama Magelang.

The implementation of the e-filling system, internet understanding, and moderation between the implementation of the e-filling system and the understanding of the internet simultaneously affect taxpayer compliance, however, the t-test results prove that understanding of the internet cannot moderate the implementation of the e-filling system to taxpayer compliance with significant value $0.305>0.05$. The results of this study reject $\mathrm{H} 3$ in the third hypothesis because the system cannot be easily understood by taxpayers, especially taxpayers who are still beginners, in addition to finding information about e-filling, sometimes the internet cannot explain in detail, and when viewed In fact, online SPT reporting using efilling can be done by anyone, so taxpayers who are not familiar with the e-filling system can ask for help from others who already understand it. The results of this study show differences with the results of the study [8].

The implementation of the e-billing system, understanding the internet, and moderation between the implementation of the e-billing system and the understanding of the internet together affect taxpayer compliance, however, the t-test results prove that understanding the internet cannot moderate the implementation of the e-billing system to taxpayer compliance. By a significance value of $0.207>0.05$. The results of this study show differences with the results of the study [10]. His research explains that understanding the Internet can moderate the implementation of the e-billing system to taxpayer compliance at KPP Pratama Gianyar. Understanding the internet cannot moderate the implementation of the e-billing system to 
taxpayer compliance because e-billing is not easy to use for novice taxpayers even though the taxpayer actually has a good understanding of the internet, besides that the taxpayer when having problems in the payment process and trying to solving the problem by using the internet, the information obtained from the internet is sometimes difficult to understand, therefore there is a need for direct socialization regarding the procedures for using and utilizing the e-billing system, especially for novice taxpayers.

\section{Conclusion}

With the results of the research data analysis, it can be concluded that the implementation of the e-filling system and the implementation of the e-billing system influence taxpayer compliance. Meanwhile, understanding the internet cannot moderate the effect of the implementation of the e-filling system and the implementation of the e-billing system on taxpayer compliance. These results illustrate that the Directorate General of Taxes has a role in disseminating e-filling and e-billing in terms of benefits that can be felt by taxpayers so that it is expected to increase taxpayer compliance. With this socialization, it will increase taxpayers' internet understanding of the use of e-filling and e-billing.

\section{References}

[1] D. Sari. “Konsep Dasar Perpajakan”, Bandung: PT Rafika Aditama, 2013.

[2] APJII. "Penggunaan Internet di Indonesia mencapai 171,17 Juta Terbesar di Pulau Jawa", 2019.

[3] R. R. Sari and T. Erawati, "Pengaruh penerapan efiling terhadap kepatuhan wajib pajak dalam menyampaikan SPT tahunan dengan kepuasan kualitas pelayanan sebagai variabel intervening", J. Ekon. Akunt, vol. 6, no. 1, pp. 1-10, 2018, doi: 10.24964/ja.v6i1.427.

[4] W. Handayani, "Pengaruh Penerapan Billing System Terhadap Kepatuhan Wajib Pajak Dengan Moderasi Pemahaman Perpajakan (Studi Pada KPP Pratama Surabaya Karangpilang)", J. Ekon. Akunt. vol. 3, no. 4, p. 115, 2017.

[5] S. B. Arifin and I. Syafii, "Penerapan E-Filing, E-Billing Dan Pemeriksaan Pajak Terhadap Kepatuhan Wajib Pajak Orang Pribadi Di Kpp Pratama Medan Polonia,” J. Ekon. Akunt, vol. 5, no. 1, p. 9, 2019, doi: 10.31289/jab.v5i1.1979.

[6] T. Newcomb and F. Heider, "The Psychology of Interpersonal Relations", Am. Sociol. Rev., 1958, doi: 10.2307/2089062.

[7] F. B. Azyarah, "Pengaruh Penerapan Sistem E-registration E-SPT dan E-filling Terhadap Kepatuhan Wajib Pajak Orang Pribadi Pada KPP Pratama Semarang Timur", 2017.

[8] S. Nurhidayah, "Pengaruh Penerapan Sistem E-filling Terhadap Kepatuhan Wajib Pajak dengan Pemahaman Internet Sebagai Variabel Pemoderasi Pada KPP Pratama Klaten", Universitas Negeri Yogyakarta, 2015.

[9] F. D. Davis, "A technology acceptance model for empirically testing new end-user information systems: Theory and results", Management, 1985, doi: oclc/56932490.

[10] A. Y. I Wayan Mei Soma Eka Pratama and I. M. Sudiartana, "Pengaruh Penerapan Sistem E-Filing Dan E-Billing Terhadap Kepatuhan Wajib Pajak Dengan Pemahaman Internet Sebagai Variabel Moderasipada Kpp Pratama Gianyar”, J. Sains, Akunt. dan 
Manaj., vol. 1, no. 4, pp. 449-488, 2019.

[11] R. N, "Pengaruh Tax Amnesty Dan Sanksi Pajak Terhadap", vol. 4, no. 1, pp. 211-226, 2016.

[12] H. Husnurrosyidah and S. Suhadi, "Pengaruh E-filling E-billing dan E-faktur Terhadap Kepatuhan Pajak pada BMT Se-Kabupaten Kudus", J. Anal. Akunt. dan Perpajak., vol. vol 1. No, 2017.

[13] Y. Prastowo, "Modernisasi Administrasi Perpajakan: Upaya Penyempurnaan Pelayanan Pajak (I)", 2017. https:/www.online-pajak.com/tentang-efiling/modernisasiadministrasi-perpajakan-upaya-penyempurnaan-pelayanan-pajak-bagian-1-1.

[14] Y. O. Lado and M. Budiantara, "Pengaruh Penerapan Sistem E-Filling Terhadap Kepatuhan Wajib Pajak Orang Pribadi Pegawai Negeri Sipil Dengan Pemahaman Internet Sebagai Variabel Pemoderasi (Studi Kasus pada Dinas Perindustrian dan Perdagangan DIY)", J. Ris. Akunt. Mercu Buana, vol. 4, no. 1, p. 59, 2018, doi: 10.26486/jramb.v4i1.498.

[15] Lina Nurlaela, "Pengaruh Penerapan E-Filling Terhadap Kepatuhan Wajib Pajak di KPP Pratama Garut", J. Wahana Akunt., vol. 2(2), pp. 1-8, 2016.

[16] M. Suherman, A. Medina, and R. Marliana, "Pengaruh Penerapan E-Filing Terhadap Kepatuhan Wajib Pajak Dalam Penyampaian Surat Pemberitahuan (SPT) Tahunan Pada Kantor Pelayanan Pajak Pratama”, Media Ris. Akuntansi, Audit. Inf., vol. 15, no. 1, pp. 49-64, 2015.

[17] E. Fauziyah, "Pengaruh Penerapan E-Billing, Pemahaman Peraturan Pemerintah Nomor 46 Tahun 2013, Dan Sanksi Perpajakan Terhadap Kepatuhan Wajib Pajak Umkm Pada Kantor Pelayanan Pajak Pratama Magelang”, 2019. 